\title{
Research Notes - Vol. 3, No. 2
}

\section{Leadership and Distance Education in Higher Education: A US perspective}

\author{
Sonja A. Irlbeck \\ University of Minnesota
}

\begin{abstract}
The premise of this article is that while in the US understanding is growing about the technologies and strategies needed for effective distance education in an online environment, leadership efforts remain weak. The article describes leadership for distance education, historical perspectives of leading distance education, and how the Internet has directly changed distance education efforts in US higher education institutions. The article concludes with an appraisal of how the approach of higher education leaders must change in order for distance education efforts to be successful.
\end{abstract}

Keywords: change; distance education; higher education; Internet; leaders; leadership; technology; policy

\section{Introduction}

The worlds of work and education are changing, and leaders in today's educational institutions need to determine how to effectively lead in the acquisition, development, and dissemination of information to tomorrow's workers. Leadership is necessary to bring cohesion to the distance education arena within higher education. Drucker (1998) maintained that in the latter part of the last century, technology resulted in a transformation of the social structure. We saw the "rise and fall of the blue-collar worker" (p. 539), the rise of the industrial worker who gave way to the rise of the knowledge worker, a term unknown prior to 1959 (p. 542). These societal and cultural changes meant leaders were challenged to rethink how they encouraged management, workers, and organizations. If as Drucker (1998, p. 551) claimed, "Knowledge has become the key resource," ways need to be found to develop and share knowledge. This is the challenge for higher education transformational leaders.

A transformation is taking place in higher education regarding technology, the Internet and education. This paper investigates some of the leadership aspects of that transformation.

\section{Technology's Influence on Higher Education}

A number of US based commissions, committees and agencies have investigated distance education for twenty-first century learning, including the Council for Higher Education Accreditation (2000) and the Web-Based Education Commission to the President and the Congress (2000). Nearly all studies have addressed technology, policy development, changes to higher education, and learners. Although recent resources are beginning to fill that gap (Bates, 
2000; Hanna, 2000; Lucas, 2000; Shoemaker, 1998), few commissions and agencies have addressed the leadership needed to make this shift possible. "With the increased capabilities of newer generations of distance education technology, postsecondary institutions are being forced to revisit, if not altogether redefine, their missions” (Lewis, Snow, and Farris, 1999, p. 5) and to rethink the leadership needed to make the transition. One report on US distance education policy (Ace Offices of Government Relations, 2000) asserts that technology and distance education are influencing higher education in a way that may not be controlled by previous structures, providers of services, or traditional policies. Different reports refer to the rate of growth in Internet based distance learning (Institute for Higher Education Policy, 2000, p. vii) or the idea that classrooms have been transformed (Web-based Education Commission, 2000, p. 1). These sources acknowledged that the present and future are going to be different from traditional classroom-based education: “... the Internet and WWW profoundly influence society in general and colleges and universities in particular. Not since the 15th century printing press has an 'invention' generated such potential to dramatically change...” (The Institute for Higher Education Policy, 2000, p. 5). Technology-based education is the most recent event to trigger dramatic demographic, economic, and social changes, which is clearly altering teaching and learning relationships in the US. This change is perhaps more significant than those that followed the Morrill Act of 1862, which created land grant colleges, and the G.I. Bill in 1944, that allowed for a large influx of students into higher education (Duning, Van Kekerix, and Zaborowski, 1993, p. 266).

Several studies have investigated the results of distance education by comparing distance education with traditional education (Boling and Robinson, 1999; Kasworm, 1997; Lewis, et al., 1999; Main and Riise, 1995; National Center for Educational Statistics, 1999). However, limited attention was given to administrative aspects of distance learning programs (Chang; 1998; Irlbeck, 2001; Lape and Hart, 1997). Whether distance education is more or less effective than traditional education is no longer a question requiring investigation. The Web-Based Education Commission to the President and the Congress (2000) is one of the most recent panels of experts to issue a call to action regarding distance education in the US. This panel listed the following action points related to effective leadership:

- Make powerful new Internet resources, especially broadband access, widely and equitably available and affordable for all learners

- Provide continuous and relevant training and support for educators and administrators at all levels

- Build a new research framework of how people learn in the Internet age

- Develop high quality online educational content that meets the highest standards of educational excellence

- Revise outdated regulations that impede innovation and replace them with approaches that embrace anytime, anywhere, any place learning

- Protect online learners and ensure their privacy

- Sustain funding - via traditional and new sources - that is adequate to the challenge at hand. Technology is expensive, and web-based learning is no exception. (Web-based Education Commission, 2000, p. iii-iv).

Institutional leadership needs to be exercised in new ways in order to accomplish such action points described above. Hanna (2000) maintains: "There is a critical need for bold leaders who can help shape the changes that are transforming our colleges and universities. . . the task and challenge of leadership and of developing new paths for the future of both traditional and new universities would be daunting” (p. 12 -13). Hanna insists that research is still needed to study characteristics required for distance education programs to grow and be successful in colleges and universities.

Recent statistics show that Internet-based distance education programs are growing exponentially in the US, primarily because of the availability of the Internet (National Center 
for Education Statistics, 1999). The postsecondary online market is currently estimated at US $\$ 1.2$ billion and is expected to grow to US $\$ 7$ billion by 2003. Nearly 710,000 students were enrolled in distributed learning courses in 1998, with an expected 2.2 million students enrolling in 2002. Despite rising enrollments, only 16 percent of students fit the profile of traditional students, those aged 18 to 22 year old, who attend full-time and live on campus (Web-based Education Commission, 2000). Examples of collaboration and implementation of distance education offerings in higher education include expanding partnerships with research universities to form online directories of courses, two- and four-year colleges in various states creating distance-learning consortiums, and grants for course redesigns (Council for Higher Education Accreditation, 2000). These opportunities and changes in the way higher education is implemented require thoughtful and effective leadership. Yet for some, distance education represents a new area of activity. As a result, bold new ways of thinking are being asked of higher education administrators, a group that has generally not previously been asked to respond to innovation.

The US can learn lessons about leadership and distance education from successful international distance education institutions such as the British Open University, Athabasca University Canada's Open University, and Australia's Deakin University. With discussions in American colleges and universities relating to guideline and policy revisions, the trend to form new leadership patterns are becoming apparent. For example, the American Council on Education created a task force on distance learning in 1995-96, whose goal was to create guiding principles that apply to learners, providers of learning, and others who oversee learning quality and effectiveness in formal education programs. This task force identified five categories: 1) learning design; 2) learner support; 3) organizational commitment; 4) learning outcomes; and 5) technology. The Council's call for effective visionary leadership is captured in its principles for organizational commitment: "Distance learning initiatives must be backed by an organizational commitment to quality and effectiveness in all aspects of the learning environment" (American Council on Education, 1996, p. 15).

If US higher education is to maintain its leadership position regarding innovation in education, the time has come for US based leaders in higher education to incorporate viable distance education modalities into its mainstream. This requires leadership. Shoemaker (1998) poses the question: "What kind of person is needed to lead . . . ? There is little education for the management of this field, which brings a peculiar need for the understanding of academic culture and mores, together with a need for excellent modern management skills that encourage creativity, and marketing knowledge and skills. These elements comprise a framework to support pursuit of these challenges, and are needed in order to keep pace with a fast changing market . . ." (p. 2). These are some of the challenges in providing useful higher education opportunities for young students, returning students, mid-career students, and life-long learners.

\section{Leadership in Higher Education}

It will take visionary leaders and brave policy makers, coupled with dedicated instructors and savvy administrators to create new, viable, and acceptable higher education opportunities for all styles and ages of future learners. Leaders in higher education are dealing with ever increasing types of and more rapid change. This section reviews how higher education is shifting from a "convocational model” to a "convergence model," heralding a significant paradigm shift. Green makes the case that driven by new and emerging societal needs for lifelong learning coupled with advances in information technology, more learners are converging to create this paradigm shift. Distance education is integrally intertwined with this paradigm shift toward convergence. Hall (1995) describes this change as a technological revolution that is changing all learning. "Through applications of technology, the traditional university of convocation is about to become the university of convergence" (p. 12). Extending d this thought, Green (March/ April 
1999, p. 15) stated that along with research universities, residential colleges, and commuter institutions, distance education should be viewed as a fourth sector of higher education.

As higher education moves from a convocational model to one of convergence, there will most likely be corresponding changes in leadership in higher education. This transformation of leadership structures both in the US and internationally requires an understanding of the present higher education setting of convocation, issues associated with significant change, and an understanding of how to lead that change.

In the mid 1980s, Bass, who refined transformational leadership theory to its present perspective, observed that modern universities tend to "represent organizations in which transformational leadership is less likely to be seen” (1985, p. 159). However, a model of transformational leadership is needed in the area of distance education within higher education. Bass's view from 1985 has radically changed in recent years. Johnstone, from the Western Interstate Commission on Higher Education, commented that with more attention being given to distance education in colleges and universities, the issue is beginning to reach critical mass in the US (Irlbeck, 2000).

Lucas (2000) focused on the importance of changes that need to occur in US higher education, conceding that while higher education often reacts slowly to change, it has contributed to significant social change in the past as exemplified by the Morrill Act of 1862, and the implementation of the G.I. Bill in 1944. Much has been written about higher education changing from a "faculty-and-teaching model to a student-and learning-centered model" (p. 78) and that "new technologies are leading to major structural changes in the management and organization of teaching..." (p. 216). For people to remain knowledgeable and employable, learning is evolving from a discrete (i.e., four-year) activity to a continual (i.e., lifelong learning) activity. Drucker (1998) described the knowledge worker as the replacement for the blue-collar worker in the US. Knowledge workers need to be more highly educated, interact with a wide variety of people and situations, and require educational updating on a regular basis (p. 10). These requirements challenge traditional degree-granting institutions to think in new ways, and transform their current teaching/learning processes in order to meet the needs and demands of new types of learners.

Rowley, Lujan, and Dolence (1998) claimed that higher education is facing a shift in leadership. Whereas in the past, higher education institutions tended to lead societal development, and serve as centers for study and development, this role is being changed by technology and the information age (p. 16). Higher education needs to rethink issues of student access and the learning environment. These authors argue that institutions are now experiencing a radical shift, converting from institutions that provide strictly a "timeout for learning" model, to a model premised on "perpetual learning" (p. 92). In the future, higher education will be challenged to offer both models of convocation and convergence.

Several authors (American Council on Education, 1996; Bates, 2000; Kovel-Jarboe, 1997; Lape and Hart, 1997) point to categories of needs to be considered by today's higher education leaders. These categories call for higher education leaders to frame policies regarding infrastructures that support technological innovation and distance education. Table 1 summarizes these needs as viewed by four authors. 
Irlbeck- Leadership and Distance Education in Higher Education: A US perspective

Table 1. Comparison of Categories and Authors' Descriptions: Examples of categories cited in literature

\begin{tabular}{|c|c|c|c|c|}
\hline $\begin{array}{l}\text { Leadership } \\
\text { Categories }\end{array}$ & $\begin{array}{l}\text { American } \\
\text { Council on } \\
\text { Education }\end{array}$ & Bates & Kovel-Jarboe & Lape and Hart \\
\hline Planning & $\begin{array}{l}\text { Policies } \\
\text { incorporate } \\
\text { needs of } \\
\text { distance } \\
\text { education }\end{array}$ & $\begin{array}{l}\text { - Leadership, } \\
\text { vision and } \\
\text { planning (New } \\
\text { technology is } \\
\text { accompanied by } \\
\text { major change. } \\
\text { - Management } \\
\text { (Administrative } \\
\text { and academic } \\
\text { policies). }\end{array}$ & $\begin{array}{c}\text { - Quality } \\
\text { Assurance } \\
\text { - Human } \\
\text { Resources }\end{array}$ & $\begin{array}{l}\text { - } \quad \text { Planning } \\
\text { - Factors leading } \\
\text { to adoption of } \\
\text { distance education } \\
\text { \& technologies; } \\
\text { identify barriers } \\
\text { - Organizational } \\
\text { and instructional } \\
\text { changes }\end{array}$ \\
\hline Implementation & $\begin{array}{l}\text { Overall mission } \\
\text { compatible with } \\
\text { provider }\end{array}$ & $\begin{array}{l}\text { Curriculum (Use of } \\
\text { technology } \\
\text { embedded with } \\
\text { wider strategy for } \\
\text { teaching/ learning) }\end{array}$ & $\begin{array}{l}\text { Governance, } \\
\text { mission, and } \\
\text { programs }\end{array}$ & $\begin{array}{l}\text { - Mission and } \\
\text { policies } \\
\text { - Curriculum } \\
\text { issues; changes in } \\
\text { teaching/learning } \\
\text { strategies }\end{array}$ \\
\hline Resources & $\begin{array}{l}\text { Financial and } \\
\text { administrative } \\
\text { commitment }\end{array}$ & $\begin{array}{l}\text { - Funding } \\
\text { - Technology } \\
\text { Infrastructure } \\
\text { - Faculty support }\end{array}$ & $\begin{array}{l}\text { - Financial } \\
\text { - Infrastructure }\end{array}$ & Costs \\
\hline Support & $\begin{array}{l}\text { Administrative } \\
\text { and support } \\
\text { systems } \\
\text { compatible with } \\
\text { delivery systems }\end{array}$ & & Student Support & \\
\hline
\end{tabular}

As presented by Bates and others, the new visions and educational challenges that will emerge in coming years will change the way we think about and participate in higher education.

\section{A Paradigm Shift in Higher Education}

Bates (2000) referred to Daryl Le Grew, an international distance education advocate from Deakin University, Australia, who described "a paradigm shift" that is currently taking place in higher education. Examples included the transition from an industrial society to an information society, from a once only education to lifelong education. Green (1999) further summarized the issue: “. . .we are witnessing a significant evolutionary event in American higher education. This event is the emergence of distance education and distributed learning . . .” (p. 13). Informed, visionary leadership is necessary to match this change.

An example of such visionary leadership is Western Governors University (WGU), a virtual university that was envisioned and brought to fruition in the mid-1990s as a joint effort of thirteen western US states and the US territory of Guam. Several western states collaborated on this experiment, making it possible for WGU to reach an operational stage in just over three years. WGU enables individuals to remain in their existing work, family, and community roles as they broaden their options for work roles. A concern from state leaders that reinforced this effort was the ongoing loss of young adult workers when they left their home state to gain work-related skills. Rather than duplicating existing opportunities WGU proposed to serve, instead and from its inception in late 1995, WGU envisioned itself more as a conduit to existing distance education opportunities.

The idea that blossomed into Western Governors University began to take shape when a planning document describing vision, goals, and a design plan was presented and accepted. The 
first three degree and certificate programs became available to students in 1998. By offering competency-based degrees, Western Governors University created a niche for itself that enhanced the role of community colleges in the western states and Guam, and provided both leadership and incentives for thinking about new approaches to higher education.

How was this bold initiative accomplished? WGU was a true blending of talents with underlying goal of creating a "global learning community." New educational options and opportunities became potentially available to every community in the western states and territory of the United States. Rapid implementation of this goal was made possible by the dedication, commitment, and leadership by a team of people, coupled with strong and continued support from business, education, and political leaders in the states.

\section{Conclusion}

As technology-enhanced distance education gains greater acceptance, it will gain stature as a distinct entity that represents high quality education, providing opportunities to students no matter where they are located. Tichy (1986, p. 4) wrote: “Transforming an organization also requires a new vision, new frames for thinking about strategy, structure, and people. While some ... can start with a clean slate, transformational leaders must begin with what is already in place.” As they transition from the old leadership paradigm toward a new vision, incorporating newer technologies and creating the structures, policies and other supports for viable distance education programs, this is the role that transformational leaders must play in today's colleges and universities.

The higher education world is changing, and opportunities created by technology coupled with the possibilities of distance education are exciting and intimidating at the same time. These changes call for program directors, department leaders, deans, and faculty to demonstrate transformational leadership. Working together to exercise leadership in discussing, planning and implementing the required changes while, at the same time, focusing on the central importance of students and content delivery, will provide the best that education has to offer.

\section{References}

Ace Offices of Government Relations, P. A., and General Counsel, (2000). Developing a Distance Education Policy for 21st Century Learning. Division of Government and Public Affairs. Retrieved July 5, 2001 from: http://www.acenet.edu/washington/distance_ed/2000/03march/distance_ed.html

American Council on Education. (1996). Guiding Principles for Distance Learning in a Learning Society. Washington, D.C.: American Council on Education, Center for Adult Learning and Educational Credentials.

Bass, B. M. (1985). Leadership and Performance Beyond Expectations. New York: The Free Press.

Bates, A. W. (2000). Managing Technological Change: Strategies for college and university leaders. San Francisco: Jossey-Bass Publishers.

Boling, N. C., and Robinson, D. H. (1999). Individual Study, Interactive Multimedia, or Cooperative Learning: Which Activity Best Supplements Lecture-based Distanceeducation? Journal of Educational Psychology 91(1). 169 - 174. 
Irlbeck-Leadership and Distance Education in Higher Education: A US perspective

Chang, V. (1998). Policy Development for Distance Education (ECO-JC-98-13). Los Angeles, CA: ERIC.

Council for Higher Education Accreditation. (2000). Distance Learning in Higher Education: CHEA Update Number 3. Council for Higher Education Accreditation.

Drucker, P. F. (1998). The Age of Social Transformation. In G. R. Hickman (Ed.) Leading Organizations: Perspectives for a New Era (p. 538-556). Thousand Oaks, CA.: SAGE Publications.

Duning, B. S., Van Kekerix, M. J., and Zaborowski, L. M. (1993). Reaching Learners Through Telecommunications. San Francisco: Jossey-Bass.

Green, K. C. (1999). When Wishes Come True: Colleges and the Convergence of Access, Lifelong Learning, and Technology. Change March/April. 11 - 15.

Hall, J. (1995). The Revolution in Electronic Technology and the Modern University: The Convergence of Means. In Y. Evans and D. Nation (Eds.) Opening Education: Policies and Practices from Open and Distance Education. New York: Routledge.

Hanna, D. E. (2000). Higher Education in an Era of digital Competition: Choices and Challenges. Madison, WI.: Atwood Publishing.

Irlbeck, S. (2000). Interview with Johnson for paper, Dimensions of Leadership in Higher Education Distance Education. St. Paul: unpublished.

Irlbeck, S. A. (2001). Leadership and Distance Education. Educational Doctoral dissertation, University of Minnesota, Minneapolis, MN. unpublished.

Kasworm, C. E. (1997). The Agony and the Ecstasy of Adult Learning: Faculty Learning Computing Technology: What Lessons can we Learn from these Experiences? Paper presented at the Annual Meeting of the American Association for Adult and Continuing Education. ED-416-402: ERIC.

Kovel-Jarboe, P. (1997). From the margin to the mainstream: State-level policy and planning for distance education. New Directions for Community Colleges 99. 23 - 32: JosseyBass Publishers.

Lape, D. H., and Hart, P. K. (1997). Changing the Way we Teach by Changing the College: Leading the way together. New Directions for Community Colleges 99, 15 - 22.

Lewis, L., Snow, K., and Farris, E. (1999). Distance Education at Postsecondary Education Institutions: 1997-98 National Center for Education Statistics (NCES). Washington, D. C.: U. S. Department of Education, Office of Educational Research and Improvement.

Lucas, A. F. (2000). Leading Academic Change: Essential roles for department chairs. San Francisco: Lucas and Associates.

Main, R. G., and Riise, E. (1995). A Study of Interaction in Distance Learning (interim Technical Report AL/HR-TP-1994-0037). Chico, CA.: California State University. 
National Center for Education Statistics (1999). Distance Education at Postsecondary Education Institutions: 1997-98. Washington D. C.: U. S. Department of Education, Office of Educational Research and Improvement.

Rowley, D. J., Lujan, H. D., and Dolence, M. G. (1998). Strategic Choices for the Academy: How demand for lifelong learning will re-create higher education. San Francisco, CA: Jossey-Bass.

Shoemaker, J. C. C. (1998). Leadership in Continuing and Distance Education in Higher Education. Boston, MA.: Allyn and Bacon.

The Institute for Higher Education Policy (1999). What's the Difference? A Review of Contemporary Research on the Effectiveness of Distance Learning in Higher Education. The Institute for Higher Education Policy. Retrieved August 10, 2002 from: http://www.educause.edu/asp/doclib/abstract.asp?ID=CSD1488

Tichy, N. M., and Devanna, M. A. (1986). The Transformational Leader. New York: John Wiley and Sons.

Web-based Education Commission. (2000). The Power of the Internet for Learning: Moving from Promise to Practice. Washington, D. C.: Education Publications Center, U. S. Department of Education.

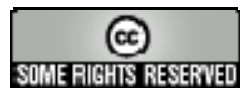

